\title{
2018 APSA Organized Section Awards
}

I $n$ addition to the APSA awards, the following recognitions were announced by the APSA Organized Sections.

SECTION 01. FEDERALISM \& INTERGOVERNMENTAL RELATIONS

\section{Martha Derthick Book Award}

The Martha Derthick Book Award is conferred for the best book published at least 10 years ago that has made a lasting contribution to the study of federalism and intergovernmental relations.

Award Committee: Paul Nolette, Chair, Marquette University; Maria Escobar-Lemmon, Texas A\&M University; Barry Rabe, University of Michigan

Recipient: Wallace Oates, University of Maryland

Title: Fiscal Federalism. Harcourt Brace, 1972.

\section{Daniel Elazar Distinguished Federalism Scholar Award}

The Daniel Elazar Distinguished Federalism Scholar Award recognizes distinguished scholarly contributions to the study of federalism and intergovernmental relations.

Award Committee: Jennifer Wolak, Chair, University of Colorado Boulder; Gary Marks, University of North Carolina at Chapel Hill; Craig Volden, University of Virginia

Recipient:Fritz Scharpf, Max Planck Institute for the Study of Societies

\section{Deil S. Wright Best Paper Award}

The Deil S. Wright Best Paper Award is conferred for the best paper in the field of federalism and intergovernmental relations presented at the previous year's annual meeting of the APSA.

Award Committee: Charles Hankla, Chair, Georgia State University; Mona Vakilifathi, New York University; Jason Sorens, Dartmouth University

Recipients: David Siroky, Arizona State University; Sean Mueller, University of Bern; Michael Hechter, Arizona State University; Andre Fazi, University of Corsica

Title: "The Limits of Indirect Rule: Containing Nationalism in Corsica."

\section{John Kincaid Best Article Award}

The John Kincaid Best Article Award is conferred on the author(s) of the best article published in Publius: The Journal of Federalism in the previous year.

Award Committee: Srinivas Parinandi, Chair, University of Colorado Boulder; Duane Milne, West Chester University; Vladimir Kogan, Ohio State University Recipient: Nicholas Jacobs, University of Virginia

Title: "An Experimental Test of How Americans Think about Federalism." Publius: The Journal of Federalism 47: 572-598

\section{SECTION 02. LAW AND COURTS}

\section{Best Graduate Student Paper Award}

The Best Graduate Student Paper Award is given annually for the best paper on law and courts written by a graduate student.

Award Committee: Jeffrey Yates, Chair, State University of New York at Binghamton; Deborah Beim, Yale University; Bethany Blackstone, University of North Texas; Rebecca Hamlin, University of Massachusetts at Amherst; Maxwell Mak, CUNY, John Jay

Recipients: Nancy B. Arrington, Emory University

Title: "Gender and Judicial Replacement: The Case of US State Supreme Courts." Journal of Law and Courts. 2018.

\section{Teaching and Mentoring Award}

The Teaching and Mentoring Award recognizes innovative teaching and instructional methods and materials in law and courts. Examples of innovations that might be recognized by this award include (but are not limited to) outstanding textbooks, websites, classroom exercises, syllabi, or other devices designed to enhance the transmission of knowledge about law and courts to undergraduate or graduate students.

Award Committee: Rebecca Gill, Chair, University of Nevada, Las Vegas; Ali S. Masood, California State University, Fresno; Salmon Shamade, University of New Orleans; Chad Westerland, University of Arizona; Michael Zilis, University of Kentucky

Recipient: Bethany Blackstone, University of North Texas

\section{Lasting Contribution Award}

The Lasting Contribution Award is given annually for a book or journal article, 10 years or older, that has made a lasting impression on the field of law and courts. Award Committee: Robert M. Howard, Chair, Georgia State University; Shenita Brazilton, Old Dominion University; Brett Curry, Georgia State University; Virginia Hettinger, University of Connecticut, Claire Wofford, College of Charleston Recipient: Melinda Gann Hall, Michigan State University

Title: "Electoral Politics and Strategic Voting in State Supreme Courts." Journal of Politics 54(2): 427-446.

\section{Lifetime Achievement Award}

The Lifetime Achievement Award is an award for a lifetime of significant scholarship, teaching, and service to the law and courts field.

Award Committee: Melinda Gann Hall, Chair, Michigan State University; Taneisha Means, Vassar College; Timothy Johnson, University of Minnesota; Amy Steigerwald, Georgia State University; Paul Wahlbeck, George Washington University

Recipient: Jeffrey Segal, Stony Brook University

\section{Best Conference Paper Award}

The Law and Courts Best Conference Paper Award (formerly the American Judicature Society Award) is given annually for the best paper on law and courts presented at the previous year's annual meetings of the American, international, or regional political science associations. Single and coauthored papers, written by political scientists, are eligible. Papers may be nominated by any member of the section.

Award Committee: Valerie Hoekstra, Chair, Arizona State University; Eileen Braman, Indiana University; Michael Fix, Georgia State University; Banks Miller, University of Texas at Dallas; John Patty, University of Chicago

Recipient: Morgan L.W. Hazelton, St. Louis University; Racheal K. Hinkle, State University of New York at Buffalo; Michael Nelson, Penn State University

Title: "The Elevator Effect: How Collegiality Fosters Public Consensus." MPSA 2017.

Honorable Mention: Nancy Arrington, Leeann Bass, Adam Glynn, Jeffrey K. Staton, and Brian Delgado, Emory University; Staffan Lindberg, University of Guttenberg 
Title: "Appointment Rules and Gender Diversity on High Courts.” MPSA 2018.

\section{Law and Courts Service Award}

The Law and Courts Service Award recognizes service to the section in the literal sense, as in service on committees and in leadership positions, as well as service within the section, as in service to the profession within the field of law and courts in the form of archiving data, promoting infrastructure, representing the profession in the media, etc. Award Committee: Richard Pacelle, Chair, University of Tennessee; Terri Perreti, Santa Clara University; Greg Goelzhauser, Utah State University; Gbemende Johnson, Hamilton College; Todd Collins, Western Carolina University

Recipient: Wendy Martinek, State University of New York at Binghamton

\section{Herman Pritchett Award for Best Book in Law and Courts}

The C. Herman Pritchett Award is given annually for the best book on law and courts written by a political scientist and published the previous year (2016).

Award Committee: Ryan Black, Chair, Michigan State University; Drew Lanier, University of Central Florida; Alicia UribeMcGuire; University of Illinois; Michael Nelson, Penn State University; Ezequiel Gonzalez Ocantos, Oxford University Recipient: Lawrence Baum, Ohio State University

Title: Ideology in the Supreme Court. Princeton University Press, 2018.

\section{SECTION 03. LEGISLATIVE STUDIES}

\section{Richard F. Fenno Prize}

In the tradition of Professor Fenno's work, this prize is designed to honor work that is both theoretically and empirically strong. Moreover, this prize is dedicated to encouraging scholars to pursue new and different avenues of research in order to find answers to previously unexplored questions about the nature of politics.

Award Committee: Douglas L. Kriner, Chair, Penn State University; Rebecca Thorpe, University of Washington; Bill Bianco, Indiana University

Recipients: Sarah A. Binder, George Washington University/Brookings Institute and Mark Spindel, Potomac River Capital, LLC

Title: "The Myth of Independence: How Congress Governs the Federal Reserve." Princeton University Press, 2017.

\section{Carl Albert Dissertation Award}

The Carl Albert Dissertation Award is given annually for the best dissertation in legislative studies. Topics may be national or subnational in focus on the topic of Congress, parliaments, state legislatures, or other representative bodies.

Award Committee: Michelle Whyman, Chair, Duke University; Anthony Madonna, University of Georgia; Jason Casellas, University of Houston

Recipient: Alison W. Craig, University of Texas at Austin

Title: "Crafting a Broad Appeal: Congressional Audiences and Policy Collaboration in the Modern Legislature." Ohio State University

\section{Jewell-Loewenberg Award}

The Jewell-Loewenberg Award recognizes the best article in the Legislative Studies Quarterly in the previous year.

Award Committee: Doug Ahler, Chair, Florida State University; Sharece Thrower, Vanderbilt University; Gisela Sin, University of Illinois

Recipients: Sarah Anzia, University of California, Berkeley and Terry Moe, Stanford University

Title: "Polarization and Policy: The Politics of Public-Sector Pensions." Legislative Studies Quarterly 42(1): 33-62.

\section{Alan Rosenthal Prize}

In the spirit of Alan Rosenthal's work, this prize is dedicated to encouraging young scholars to study questions that are of importance to legislators and legislative staff and to conduct research that has the potential application to strengthening the practice of representative democracy.

Award Committee: Tiffany Barnes, Chair, University of Kentucky; Amanda Driscoll, Florida State University; Nathaniel Birkhead, Kansas State University

Recipient: Ruth Bloch Rubin, University of Chicago

Title: Building the Bloc: Intraparty Organization in the USCongress. Cambridge University Press, 2017.

\section{CQ Press Award}

The CQ Press Award for the best paper on legislative studies presented at the previous year's APSA Annual Meeting.

Award Committee: Stuart Soroka, Chair, University of Michigan; Sebastian Saiegh, University of California at San Diego; Wendy Schiller, Brown University
Recipients: Olle Folke, Uppsala University and Johanna Rickne, Stockholm University Title: "The ballot rank hierarchy and the irrelevance of marginal seats: Party nomination strategies in closed and flexible PR."

\section{Barbara Sinclair Legacy Award}

The Barbara Sinclair Legacy Award is designed to honor the work of a scholar or set of scholars who have contributed a lifetime of significant scholarship to the study of legislative politics. In the tradition of Professor Sinclair's body of work, recipients of this award will have focused on individual legislative behavior, institutional rules, or the role of party in shaping legislative politics. This award is also intended to recognize scholars who employ a range of methods in their research. Award Committee: Gregory Koger, Chair, University of Miami; Sarah Binder, George Washington University/Brookings Institute; Lynda Powell, University of Rochester Recipient: David R. Mayhew, Yale University

\section{Emerging Scholar Award}

The Emerging Scholar award is designed to recognize a scholar who is no more than 6 years from the year of their $\mathrm{PhD}$ who has informed the study of legislative politics through innovative and rigorous scholarship. The recipient of this award will be an individual who has a strong early career publication trajectory, and has presented their work actively at conferences and other public venues.

Award Committee: Laurel Harbridge, Chair, Northwestern University; Leslie SchwindtBayer, Rice University; Michael Crespin, University of Oklahoma

Recipients: Tiffany D. Barnes, University of Kentucky and Justin H. Kirkland, University of Houston

\section{SECTION 04. PUBLIC POLICY}

\section{Aaron Wildavsky Enduring Contribution Award}

The Aaron Wildavsky Enduring Contribution Award is given for the best book or article published in the general area of public policy during the past 20-plus years.

Award Committee: Kenneth Wong, Brown University; Joseph White, Case Western University; John Wilkerson, University of Washington

Recipient: R. Kent Weaver, Georgetown University

Title: "The Politics of Blame Avoidance." Journal of Public Policy, 1986 
Best Comparative Policy Paper Award (with JCPA)

The Best Comparative Policy Paper Award is given to a scholar who has received his or her PhD within the last five years and whose career to date demonstrates unusual promise.

Award Committee: Lindsay Flynn, Chair, Wheaton College; Sofia Perez, Boston University; Pavithra Suryanarayan, Johns Hopkins University; Jacint Jordana Casajuana, Universidad Pompeu Fabra; Xufeng Zhu, Tsinghua University Recipients: Amelia Peterson, Harvard University

Title: "Incentivizing higher skills - but whose? The politics of credential reform in Liberal Market Economies."

\section{Best Paper on Public Policy Award}

The Best Paper on Public Policy Award recognizes the best paper on public policy given at the previous APSA Annual Meeting. Award Committee: Paul Quirk, Chair, University of British Columbia; Jennifer Clark, University of Houston; Molly Reynolds, Brookings Institution

Recipient: Laurel Eckhouse, University of Denver

Title: "Everyday Risk: Disparate Exposure and Racial Inequalities in Police Violence."

\section{Theodore J. Lowi Policy Studies Journal Best Article Award}

The Theodore J. Lowi Policy Studies Journal Best Article Award is given to recognize an article of particular distinction published at any time in Policy Studies Journal.

Award Committee: Craig Thomas, University of Washington; Lilliard Richardson, Indiana University; Mona Vakilifathi, New York University

Recipients: Karin Ingold, University of Bern; Manuel Fischer, Swiss Federal Institute of Aquatic Science and Technology; Paul Cairney, University of Stirling

Title: "Drivers for Policy Agreement in Nascent Subsystems: An Application of the Advocacy Coalition Framework to Fracking Policy in Switzerland and the UK." Policy Studies Journal. 45(3).

\section{Excellence in Mentoring Award}

The Excellence in Mentoring Award has been established to recognize sustained efforts by a senior scholar to encourage and facilitate the career of emerging political scientists in the field of public policy.
Award Committee: Alan Jacobs, University of British Columbia; Karen Jusko, Stanford University; James Savage, University of Virginia; Patricia Strach, University at Albany

Recipient: Bruce Cain, Stanford University and Julia Lynch, University of Pennsylvania

\section{SECTION 05. POLITICAL ORGANIZATIONS AND PARTIES}

\section{Emerging Scholars Award}

The Emerging Scholars Award is given to a scholar who has received his or her $\mathrm{PhD}$ within the last five years and whose career to date demonstrates unusual promise.

Award Committee: Michael Heaney, Chair, University of Michigan; Lilliana $\mathrm{H}$. Mason, University of Maryland, College Park; Janet Box-Steffensmeier, Ohio State University

Recipient: Ann-Kristin Kölln, Aarhus University

\section{Jack Walker Award}

The Jack Walker Award recognizes an article published in the last two calendar years that makes an outstanding contribution to research and scholarship on political organizations and parties.

Award Committee: Heath Brown, Chair, CUNY Graduate Center; Michael Franz, Bowdoin College; Diana Dwyre, California State University, Chico

Recipients: Jonathan Polk, University of Gothenburg and Ann-Kristin Kölln, Aarhus University

Title: "Electoral Infidelity: Why party members cast defecting votes."

\section{Leon D. Epstein Outstanding Book Award}

The Leon D. Epstein Outstanding Book Award recognizes a book published in the last two calendar years that made an outstanding contribution to research and scholarship on political organizations and parties.

Award Committee: Karen Beckwith, Chair, Case Reserve University; Rory Truex, Princeton University; Thomas Holyoke, California State University, Fresno Recipients: Matt Grossman and David Hopkins, Boston College

Title: Asymmetric Politics: Ideological Republicans and Group Interest Democrats. Oxford University Press, 2016.

\section{SECTION 06. PUBLIC ADMINISTRATION}

\section{Herbert Kaufman Award}

Best paper presented on a panel sponsored (or co-sponsored) by the Public Administration section at the APSA Annual Meeting each year.

Award Committee: Morgen Johansen, Chair, University of Hawaii; Gwen Arnold, University of California, Davis; Andrew Whitford, University of Georgia

Recipients: Angel Molina, Arizona State University and Nathan Favero, American University

Title: "Inclusion, Accountability, and the Urban/Rural Divide."

\section{Herbert A. Simon Best Book Award}

The Herbert A. Simon Book Award is given for significant contributions to public administration scholarship.

Award Committee: John Patty, Chair, University of Chicago; Daniel Hawes, Kent State University; Sharece Thrower, Vanderbilt University

Recipient: Rachel VanSickle-Ward, Pitzer College

Title: The Devil is in the Details. SUNY Press, 2014.

Recipient: Daniel Sabet, Social Impact Title: Police Reform in Mexico: Informal Politics and the Challenge of Institutional Change. Stanford University Press, 2012.

\section{Paul A. Volcker Junior Scholar Research Grant Award}

The Paul A. Volcker Junior Scholar Research Grant Award is awarded to junior scholars researching public administration issues that affect governance in the United States and abroad. Proposals will be judged on their potential to shed new light on important public administration questions, their scholarly and methodological rigor, and their promise for advancing practice and theory development.

Award Committee: Domonic Bearfield, Rutgers University; Chris Adolph, University of Washington; Xufeng Zhu, Tsinghua University

Recipient: Gordon Abner, University of Texas

\section{SECTION 07. CONFLICT PROCESSES}

\section{Lifetime Achievement Award}

The Lifetime Achievement award is given every other year in recognition of scholarly contributions that have fundamentally 
improved the study of conflict processes. Award Committee: Benjamin O. Fordham, Chair, Binghamton University; Reşat Bayer, Koç University; Alyssa Prorok, University of Iowa

Recipient: John A. Vasquez, University of Illinois, Urbana-Champaign

\section{J. David Singer Data Innovation Award}

The J. David Singer Data Innovation Award is given biennially for the best data contribution to the study of any and all forms of political conflict, either within or between nation-states. Nominations must be made by a member of the Conflict Processes section. Self-nominations are encouraged. Award Committee: Kristian Skrede Gleditsch, Chair, University of Essex; Alex Braithwaite, University of Arizona; Patricia Sullivan, University of North Carolina at Chapel Hill Recipients: Cullen Hendrix, University of Denver and Idean Salehyan, University of Texas at Dallas

Title: The Social Conflict Analysis Database (SCAD)

\section{Best Paper Award}

This award is given annually for the best paper written by one or more untenured scholars (graduate students, postdocs, or faculty) and presented as part of a conflict processes sponsored panel or poster session at the previous APSA Annual Meeting. Papers are eligible only if all authors are untenured at the time the paper is presented. Nominations must be made by a member of the Conflict Processes section. Selfnominations are encouraged.

Award Committee: Krista Wiegand, Chair, University of Tennessee, Knoxville; Neil Narang, University of California, Santa Barbara; Daina Chiba, University of Essex Recipients: Thomas Chadefaux, Trinity College Dublin

Title: "The Price is Right: Market Anticipation of the Cost of War."

\section{Best Book Award}

Given every two years for the book making the most outstanding contributions to the study of any and all forms of political conflict, either within or between nation-states, published in the two calendar years prior to the year in which the award is given. Edited volumes and textbooks are not eligible for the award. Nominations must be made by a member of the Conflict Processes section; selfnominations are encouraged.
Award Committee: Scott Straus, Chair, University ofWisconsin-Madison; Sarah Croco, University of Maryland, College Park; Scott Wolford, University of Texas at Austin Recipients: Sabrina Karim, Cornell University and Kyle Beardsley, Duke University Title: Equal Opportunity Peacekeeping: Women, Peace, and Security in Post-Conflict States. Oxford University Press, 2017.

SECTION 08. REPRESENTATION AND ELECTORAL SYSTEMS

\section{George H. Hallet Award}

The George H. Hallett Award is presented annually to the author of a book published at least 10 years ago that has made a lasting contribution to the literature on representation and electoral systems.

Award Committee: Anne Phillips, Chair, London School of Economics; Emily Beaulieu, University of Kentucky; Debra Leiter, University of Missouri - Kansas City

Recipients:Pippa Norris, Harvard University and Joni Lovenduski, Birkbeck, University of London

Title: Political Recruitment: Gender, Race, and Class in the British Parliament. Cambridge University Press, 1995.

\section{Lawrence Longley Award}

The Lawrence Longley Award is given for the best article published in the previous year.

Award Committee: Orit Kedar, Chair, Hebrew University of Jerusalem; Tarik Abou-Chadi, University of Zurich; Erika Moreno, Creighton University

Recipients: Zoltan Hajnal, University of California, San Diego; Nazita Lajevardi, Michigan State University; Lindsay Nielson, TechWerks

Title: "Voter Identification Laws and the Suppression of Minority Votes." The Journal of Politics 79(2): 363-379.

\section{Leon Weaver Award}

The Leon Weaver Award is given for the best paper presented at the previous year's APSA Annual Meeting at a panel sponsored by the Representation and Electoral Systems Division.

Award Committee: Magda Hinojosa, Chair, Arizona State University; Jana Morgan, University of Tennessee; Kristin Wylie, James Madison University

Recipient: Jennifer L. Merolla, University of California, Riverside; Abbylin H. Sellers, Azusa Pacific University; Danielle Casarez Lemi, Southern Methodist University
Title: "Does the presence of women in elected office increase female empowerment? Using an experimental approach to look at the effects of descriptive representation."

\section{SECTION 09. PRESIDENTS AND EXECUTIVE POLITICS}

\section{Richard E. Neustadt Award for Best Book on Executive Politics}

The Richard E. Neustadt Award for the Best Book on Executive Politics recognizes a book published during the year that contributed to research and scholarship on the American presidency.

Award Committee: Terri Bimes, University of California, Berkeley; Graham Dodds, Concordia University; Bat Sparrow, University of Texas at Austin; Lori Cox Han, Chapman University

Recipient: Amnon Cavari, IDC Herzliya

Title: The Party Politics of Presidential Rhetoric. Cambridge University Press, 2017.

Recipient: Trygve Throntveit, University of Minnesota

Title: Power Without Victory: Woodrow Wilson and the American Internationalist Experiment. University of Chicago, 2017.

\section{The Legacy Award}

The Legacy Award will be given to a living author for a book, essay, or article, published at least 10 years prior to the award year that has made a continuing contribution to the intellectual development of the fields of presidency and executive politics.

Award Committee: Chuck Walcott, Virginia Tech University; Randall Adkins, University of Nebraska, Omaha; Julia Azari, Marquette University; Brandon Rottinghaus, University of Houston; Richard Ellis, Williamette University

Recipient: Jeffrey Tulis, University of Texas at Austin

Title: The Rhetorical Presidency. Princeton University, 1987.

\section{Founder's Best Paper Award}

The Founders Award-honoring James Sterling Young-recognizes the best paper on executive politics authored by a PhDholding scholar at the 2016 APSA Annual Meeting.

Award Committee: Richard Waterman, University of Kentucky; Scott James, University of California, Los Angeles; Nancy Kassop, State University of New York, New Paltz; Meena Bose, Hofstra University 
Recipients: Aaron R. Kaufman and Jon C. Rogowski, Harvard University

Title: "Interbranch Conflict, Unilateral Action, and the Presidency."

\section{Founder's Best Graduate Student Paper Award}

The Founders Award-honoring Peri Arnold-recognizes the best paper on executive politics presented by a graduate student at either the 2016 APSA Annual Meeting or at any regional meetings in 2016-2017.

Award Committee: Mark Major, Penn State University; Matthew EshbaughSoha, University of North Texas; Janna Rezaee, University of Southern California; Kevin Evans, Florida International University

Recipient: John A. Dearborn, Yale University Title: “The 'Proper Organs' for Presidential Representation: A Fresh Look at the Budget and Accounting Act of 1921."

Honorable Mention: Christina M. Kinane, University of Michigan

Title: "The Politics of Vacancies and Interim Appointments in the Bureaucracy."

\section{SECTION 10. POLITICAL}

METHODOLOGY

\section{Society for Political Methodology Poster Award}

This award recognizes the best political methodology poster given at any political science conference in the preceding year. Award Committee: John Londregan, Princeton University; Adam Berinsky, Massachusetts Institute of Technology; Dan Hopkins, University of Pennsylvania; Erin Hartman, University of California, Los Angeles; Melissa Sands, University of California, Merced; Benjamin Lauderdale, London School of Economics

Recipient: Michelle Torres, Washington University in St. Louis

Title: "Measuring Visual Messages: Political Violence and Computer Vision."

Recipient: John Jackson, University of Michigan

Title: "Correct Standard Errors with Clustered Data."

\section{Career Achievement Award}

The Career Achievement Award honors an outstanding career of intellectual accomplishment and service to the profession in the Political Methodology field.

Award Committee: Robert Franzese, Chair, University of Michigan; Lonna Atkeson,
University of New Mexico; Jeffrey Lewis, University of California, Los Angeles; Simon Jackman, University of Sydney; Wendy Tam Cho, University of Illinois at Urbana-Champaign, Michael Ward, Duke University

Recipient: Michael D. Ward, Duke University

\section{Excellence in Mentoring Award}

The Society for Political Methodology Excellence in Mentoring Award honors members of the Society for Political methodology who have demonstrated an outstanding commitment to mentoring and advising graduate and/or undergraduate students-particularly those from underrepresented groups.

Award Committee: Maya Sen, Chair, Harvard University; Henry Brady, University of California, Berkeley; Phillip Shrodt, Parus Analytics

Recipient: Thomas Casey, University of North Carolina at Chapel Hill

\section{Warren Miller Prize}

The Warren Miller Prize is given for the best article in political analysis.

Award Committee: Jens Hainmueller, Chair, Stanford University; Jennifer Pan, Stanford University; Jonathan Katz, California Institute of Technology; Pablo Barbera, London School of Economics

Recipient: Yiqing Xu, University of California, San Diego

Title: "Generalized Synthetic Control Method: Casual Inference with Interactive Fixed Effect Models." Political Analysis 25(1)

\section{Statistical Software Award}

The Statistical Software Award recognizes statistical software that has made a significant contribution to the advancement of political science.

Award Committee: Adam Glynn, Chair, Emory University; Sarah Bouchat, Northwestern University; Jeffrey Arnold, University of Washington

Recipients: Molly Roberts, University of California, San Diego; Brandon Stewart, Princeton University; Dustin Tingley, Harvard University

Title: stm: An R package for Structural Topic Models

\section{Emerging Scholar Award}

The Emerging Scholar Award honors a young researcher, within 10 years of a degree, who is making notable contributions to the field of political methodology.

Award Committee: Suzanna Linn, Chair, Pennsylvania State University; Sunshine Hillygus, Duke University; Walter Mebane, University of Michigan; Luke Keele, Georgetown University

Recipient: Arthur Spirling, New York University

\section{Harold F. Gosnell Prize}

The Harold Gosnell Prize recognizes the best work of political methodology presented at a political science conference in the previous year.

Award Committee: Michael Peress, Chair, Stony Brook University; Matt Blackwell, Harvard University; Marc Ratkovic, Princeton University

Recipients: Fredrik Savje, Yale University; Peter Aronow, Yale University; Michael Hudgens, University of North Carolina at Chapel Hill

Title: "A Folk Theorem on Interface in Experiments."

\section{John T. Williams Dissertation Prize}

In recognition of John T. Williams' contribution to graduate training, this prize has been established for the best dissertation proposal in the area of political methodology.

Award Committee:Xun Pang, Chair, Tsinghua University; Arthur Spirling, New York University; Yiqing Xu, University of California, San Diego

Recipient: Kevin McAlister, University of Michigan

Title: "Roll Call Scaling in the US Congress: Addressing the Deficiencies."

\section{Janet M. Box-Steffensmeier \& John A.}

\section{Garcia ICPSR Scholarships}

Janet Box-Steffensmeier and John A. Garcia Scholarships are awarded by the Society for Political Methodology to encourage women and underrepresented graduate students in political science to attend the ICPSR Summer Program.

Award Committee: Saundra Schneider, Chair, Michigan State University; Adrienne Hosek, University of California, Davis; Lee Walker, University of North Texas

Recipients: Bianca DiGiovanni, University of Chicago; Kathryn Overton, University of New Mexico; Stephen Omar El-Khatib, University of California, Riverside; Andres Sandoval, Tulane University; Marco Alcocer, University of California, San Diego 
SECTION 11. RELIGION AND

POLITICS

\section{Hubert Morken Book Award}

The Hubert Morken Award is given for the best publication dealing with religion and politics published during the last two years. Award Committee: Nukhet A. Sandal, Ohio University; Jim Guth, Furman University; Ani Sarkissian, Michigan State University; Amy Erica Smith, Iowa State University Recipient: Andrew R. Lewis, University of Cincinnati

Title: The Rights Turn in Conservative Christian Politics. Cambridge University Press, 2017.

\section{Aaron Wildavsky Dissertation Award}

The Aaron Wildavsky Dissertation Award recognizes the best dissertation on religion and politics successfully defended within the last two years.

Award Committee: Daniel Bennett, Chair, John Brown University; Jonathan Agensky, Ohio University; Michelle Margolis, University of Pennsylvania

Recipient: Michael Hoffman, University of Notre Dame

Title: "Communal Religion, Sectarian Interests, and Democracy."

\section{Weber Best Conference Paper Award}

The Best Paper Award recognizes the best paper dealing with religion and politics presented at the previous years APSA Annual Meeting. The paper should address a timely and relevant topic, within the discipline and beyond, in a theoretically innovative and methodologically thorough manner.

Award Committee: Stacy Gutowski, Chair, King's College London; Jonathan C. Agensky, Ohio University; Amelie Barras, York University; Ben Gaskins, Lewis \& Clark College

Recipients: Paul Djupe, Denison University; Jacob Neiheisel, University at Buffalo; Kimberly Conger, University of Cincinnati

Title: "Are the Politics of the Christian Right Linked to States of the Non-Religious?"

\section{Politics and Religion Distinguished Reviewer Award}

In order recognize the important work involved in the peer review process, the Section Journal, Politics and Religion, will honor five outstanding reviewers per year.
Award Committee: Elizabeth Oldmixon; University of North Texas; Mehmet Gurses, Florida Atlantic University; Nicholas Tampio, Fordham University

Recipients: Paul Djupe, Denison University; Ekrem Karakoc, Binghamton University; Melanie Kolbe, The Graduate Institute, Geneva; Jacob Neiheisel, SUNY University at Buffalo; Lavinia Stan, St. Francis Xavier University

\section{SECTION 13. URBAN AND LOCAL POLITICS}

\section{Norton Long Career Achievement Award}

The Norton Long Career Achievement Award is presented annually to a scholar who has made distinguished contributions to the study of urban politics over the course of a career through scholarly publication, the mentoring of students, and public service Award Committee: Marion Orr, Brown University; Amy Bridges, University of California, San Diego; Kim Geron, California State University, East Bay Recipient: John Mollenkopf, CUNY, The Graduate Center

\section{Best Paper Award}

The Best Paper Award is given for the best paper given at an Urban Politics Section panel at the previous year's APSA Annual Meeting.

Award Committee: Peter Burns, Soka University

Recipients: Brian An, Morris Levy, and Rodney Hero, Arizona State University

\section{Clarence Stone Scholar Award}

The Clarence Stone Scholar Award recognizes up to two young scholars who are making a significant contribution to the study of urban politics. The award is to be given to up to two post-PhD scholars who are in their career (pre-tenure, or recently advanced within the last three years).

Award Committee: Todd Swanstrom, University of Missouri, St. Louis; Arturo Vega, St. Mary's University

Recipients: Miyra Holman, Tulane University and Aaron Deslatte, Northern Illinois University

\section{Susan Clarke Young Scholars Award}

The Susan Clarke Young Scholars award recognizes scholars who completed their $\mathrm{PhD}$ within the last three years (or are ABDs). Award Committee: Rodney E. Hero, Arizona State University; Alisha Caroline Holland,
Princeton University; Arnold Fleischman, Eastern Michigan University

Recipients: Patricia Kirkland, Princeton University; Peter Johansen, Princeton University

SECTION 15. SCIENCE, TECHNOLOGY, AND ENVIRONMENTAL POLITICS

\section{Elinor Ostrom Career Achievement Award}

The Elinor Ostrom Career Achievement Award is given to an individual in recognition of a lifetime contribution to the study of science, technology, and environmental politics.

Award Committee:Chris Weible, University of Colorado Denver;Aseem Prakash, University of Washington; Sarah Anderson, University of California, Santa Barbara

Recipient: Ronald Mitchell, University of Oregon

\section{Emerging Young Scholar Award}

The Emerging Young Scholar Award is given in recognition of a researcher, within 10 years of a $\mathrm{PhD}$ degree, who is making notable contributions to the field of science, technology, and environmental politics.

Award Committee: Jessica Green, New York University; Megan Mullin, Duke University; Dorothy Daley, University of Kansas Recipient: Rachel Krause, University of Kansas

\section{Lynton Keith Caldwell Award}

The Lynton Keith Caldwell Award is given for the best book on environmental politics and policy published in the past three years.

Award Committee: Leigh Raymond, Purdue University; Rob DeLeo, Bentley College; Saba Siddiki, Syracuse University

Recipient: Roger Karapin, CUNY Hunter College

Title: PoliticalOpportunities for Climate Policy: California, New York, and the Federal Government. Cambridge University Press. 2018.

Virginia M. Walsh Dissertation Award The Virginia M. Walsh Dissertation Awardin honor of a young scholar who tragically passed away-is given for the best dissertations in the field of science, technology, and environmental politics.

Award Committee: Matto Mildenberger, University of California, Santa Barbara; Iza Ding, Pittsburg University; David Shafie, Chapman University 
Recipient: Gregory Thaler, University of Georgia

Title: "Forest Governance and Global Development: The Land Sparing Fallacy in Brazil and Indonesia." Cornell University

\section{Don K. Price Award}

The Don K. Price Award recognizes the best book on science, technology, and environmental politics published in the last year.

Award Committee: Mark Buntaine, University of California, Santa Barbara; Mark Zachary Taylor, Georgia Tech; Kirsten Rodine-Hardy, Northeastern University Recipients: Eric M. Patashnik, Brown University; Alan S. Gerber, Yale University; Conor M. Dowling, University of Mississippi

Title: Unhealthy Politics: The Battle Over Evidence-Based Medicine. Princeton University Press. 2018.

\section{Evan Ringquist Best Paper Award}

The Evan Ringquist Best Paper Award is given for the best paper published in a relevant journal in the last two years. Relevant journals include political science, public administration, public policy, interdisciplinary environmental science, and science and technology studies journals.

Award Committee: Erick LaChapelle, University of Montreal; Anne Clunan, Naval Postgraduate School; Samantha Mosier, Missouri State University

Recipient: Jonas Meckling, University of California, Berkeley and Jonas Nahm, Johns Hopkins University

Title: "The Power of Process: State Capacity and Climate Policy."

\section{Paul A. Sabatier Best Conference Paper Award}

The Paul A. Sabatier Best Conference Paper Award is given for the best paper on science, technology, and environmental politics presented at the previous year's APSA Annual Meeting.

Award Committee: Chris Koski, Reed College: Heather Hodges, University of California, Santa Barbara; David Switzer, University of Missouri

Recipient: Gwen Arnold, Le And Nguyen Long, Madeline Gottlieb, Michael Bybee, Nikita Sinha, University of California, Davis

Title: "Understanding Local Fracking Regulatory Stringency."
SECTION 16. WOMEN AND POLITICS RESEARCH

\section{Best Dissertation Award}

This award is given for the best dissertation on women and politics completed and accepted in the previous year.

Award Committee: Zehra Arat, Chair, University of Connecticut; Corrine McConnaughy, George Washington University; Catherine Reyes-Householder, Centre for Social Conflict and Cohesion Studies

Recipient: Amanda Blair, University of Chicago

Title: "Going Beyond Accountability and Untangling the Politics of ConflictRelated Rape."

Recipient: Jennifer Jones, University of California, Irvine

Title: “Talk 'Like a Man': Feminine Style in the Pursuit of Political Power."

\section{Best Paper Award}

This award is given for the best paper presented at the previous year's annual meeting in the field of women and politics.

Award Committee: Kim Fridkin, Chair, Arizona State University; Mona Lee Krook, Rutgers University; Laura Sjoberg, University of Florida

Recipient:Egor Laserov, Columbia University Title: "Laws in Conflict: Legacies of War, Gender, and Legal Pluralism in Chechnya."

\section{Okin-Young Award in Feminist Political Theory}

The Okin-Young Award in Feminist Political Theory, co-sponsored by Women and Politics, Foundations of Political Theory, and the Women's Caucus for Political Science, commemorates the scholarly, mentoring, and professional contributions of Susan Moller Okin and Iris Marion Young to the development of the field of feminist political theory. This annual award recognizes the best paper on feminist political theory published in an English language academic journal during the previous calendar year.

Award Committee: Judith Grant, Chair, Ohio University; Amber Knight, University of North Carolina at Charlotte; Eileen Hunt Botting, University of Notre Dame Recipient: Nina Hagel, Bates College Title: Alternative Authenticities: Thinking Transgender Without Essence. Theory $\mathcal{E}$ Event. 20(3): 599-628. 2017.
SECTION 17. FOUNDATIONS OF POLITICAL THEORY

\section{First Book Award}

The First Book Award is given for a first book by a scholar in the early stages of his or her career in the area of political theory or political philosophy.

Award Committee: Jane Gordon, University of Connecticut; Kathi Weeks, Duke University; Elizabeth Cohen, Syracuse University Recipient: Sina Jo Kramer, Loyola Marymount University

Title: Excluded Within: The (Un)Intelligibility of Radical Political Actors. Oxford University Press. 2017.

Recipient: Siavash Saffari, Seoul National University

Title: Beyond Shariati: Modernity, Cosmopolitanism, and Islam in Iranian Political Thought. Cambridge University Press. 2017. Honorable Mention: Angelica Bernal, University of Massachusetts, Amherst Title: Beyond Origins: Rethinking Founding in a Time of Constitutional Democracy. Oxford University Press, 2017.

\section{Best Paper Award}

The Best Paper Award is given for the best paper presented on a foundations panel at the previous year's APSA Annual Meeting. Award Committee: Heather Pool Denison University; Karen Zivi, Grand Valley State University; Jeremy Scott Arnold, National University Singapore

Recipient: Sophie Smith, Oxford University Title: "Okin, Rawls, and the 'Quest for Legitimacy'."

\section{David Easton Award}

The David Easton Award is given for a book that broadens the horizons of contemporary political science by engaging issues of philosophical significance in political life through any of a variety of approaches in the social sciences and humanities.

Award Committee: Joan Cocks, Mount Holyoke; Susan Bickford, University of North Carolina at Chapel Hill; David Owen, University of Southampton

Recipient: Clare Chambers, University of Cambridge

Title: Against Marriage: An Egalitarian Defense of the Marriage-Free State. Oxford University Press. 2017.

Recipient: Barbara Arneil, University of British Columbia

Title: Domestic Colonies: The Turn Inward to Colony. Oxford University Press. 2017. 
SECTION 18. INFORMATION

TECHNOLOGY AND POLITICS

\section{Best Book Award}

The Best Book Award recognizes the best book in the area of information technology and politics. The contest is limited to books published in the previous calendar year. Award Committee: Jessica Baldwin-Philippi, Fordham University and Warigia Bowman, University of Tulsa

Recipient: Joel Penney, Montclair State University

Title: The Citizen Marketer: Promoting Political Opinion in the Social Media Age. Oxford University Press.

\section{Best Published Article Award}

The Best Published Article Award recognizes the best scholarly article published about information technology and politics. The contest is limited to articles published in the calendar year.

Award Committee: Cristian Vaccari, Loughborough University; Jennifer Connolly, University of Miami; Josh Pasek, University of Michigan

Recipients: Homero Gil de Zúñiga, University of Vienna; Brian Weeks, University of Michigan; Alberto Ardèvol-Abreu, Universidad de la Laguna

Title: "Effects of the News-Finds-Me Perception in Communication: Social Media Use Implications for News Seeking and Learning About Politics." Journal of Computer-Mediated Communication.

\section{Best Conference Paper Award}

The Best Conference Paper Award recognizes the best conference paper in the area of information technology and politics. Award Committee: Jennifer Oser, Ben-Gurion University; Kathleen Searles, Louisiana State University; Pablo Barberá; London School of Economics

Recipient: Shelley Boulianne, MacEwan University

Title: "Twenty years, thirty-five countries: Digital media effects on participation."

Honorable Mention:Andrew Guess, Princeton University; Brendan Nyhan, University of Michigan; Jason Reifler, University of Exeter Title: "Inside the fake news bubble? Consumption of online fake news in the 2016 US Election."

\section{Best Dissertation in Information Technology and Politics}

The Best Dissertation Award recognizes the best dissertation in the area of Information
Technology and Politics.

Award Committee: James Dennis, University of Portsmouth; Katherine Haenschen, Virginia Tech University; Ken Rogerson, Duke University

Recipient: Juan S. Larrosa-Fuentes, Temple University

Title: "Communication and the Body Politic: Hillary Clinton's 2016 Presidential Campaign in Philadelphia's Latino Community."

Honorable Mention: Chrysi Dagoula, University of Sheffield

Title: "The Ongoing Structural Transformations of the Digital Public Sphere(s): The Role of Journalism."

\section{SECTION 20. COMPARATIVE POLITICS}

\section{Powell Mentoring Award}

This prize, introduced in 2012, will be awarded on a bi-annual basis to a political scientist who throughout his or her career has demonstrated a particularly outstanding commitment to the mentoring of graduate students in comparative politics. The prize was named in honor of G. Bingham Powell and was initiated by his students.

Award Committee: Tasha Fairfield, Chair, London School of Economics; Torben Iversen, Harvard University; Melina Platas Izama, New York University Abu Dhabi Recipient: John Huber, Columbia University

\section{Sage Best Paper Award}

The Sage Best Paper Award is given to the best paper in the field of comparative politics presented at the previous year's APSA Annual Meeting.

Award Committee: Kenneth Greene, Chair, University of Texas at Austin; Robert Braun, Northwestern University; Jessica Gottlieb, Texas A\&M University

Recipient: Daniel Treisman, University of California, Los Angeles

Title: "Democracy by Mistake."

\section{Luebbert Best Book Award}

The Luebbert Book Award is given for the best book in the field of comparative politics published in the previous two years. Award Committee: Karen Andersen, Chair, University of Southampton; Michael Albertus, University of Chicago; Perna Singh, Brown University

Recipient: Diana Fu, University of Toronto Title: Mobilizing Without the Masses. Cambridge University Press, 2017.

Honorable Mention: Karen Jusko, Stanford University
Title: Who Speaks for the Poor? Cambridge University Press, 2017.

\section{Greg Luebbert Paper Award}

The Luebbert Article Award is given for the best article published in the American Political Science Review in the field on comparative politics in the prior two calendar years.

Award Committee: Beatriz Magaloni, Chair, Stanford University; Danny Hidalgo, Massachusetts Institute of Technology; Rachel Beatty Riedl, Northwestern University

Recipient: Noam Lupu, Vanderbilt University and Leonid Peisakhin, New York University Abu Dhabi

Title: "The Legacy of Political Violence across Generations." American Journal of Political Science. 2017.

Honorable Mention: Volha Charnysh, Princeton University and Evgeny Finker, George Washington University

Title: "The Death Camp Eldorado: Political and Economic Effects of Mass Violence." American Political Science Review. 2017.

\section{Lijphart/Przeworski/Verba Data Set Award}

The Data Set Award recognizes a publicly available data set that has made an important contribution to the field of comparative politics.

Award Committee: Taylor Boas, Chair, Boston University; Pablo Beramendi, Duke University; Frederick Solt, University of Iowa Recipients: Mitchell Seligson, Elizabeth Zechmeister, and Noam Lupu, Vanderbilt University

Title: AmericasBarometer

Honorable Mention: Mihaly Fazekas, University of Cambridge

Title:DIGIWHIST

SECTION 21. EUROPEAN POLITICS AND SOCIETY

\section{Best Article Award}

This award is given for the best article dealing with European Politics \& Society published in the last year.

Award Committee: Craig Parsons, Chair, University of Oregon; Zdenek Kudrna, University of Sazburg; Manuela Moschella, Scuola Normale Superiore

Recipients: Sara Hagemann, London School of Economics; Sara B. Hobolt, London School of Economics; Christopher Wratil, Harvard University 
Title: "Government Responsiveness in the European Union: Evidence from Council Voting." Comparative Political Studies 5o(6): 850-876.

\section{Best Book Award}

The Best Book Award is given for the best book on European Politics and society published in the previous year.

Award Committee: Nicolas Jabko, Chair, Johns Hopkins University; Amy Verdun, University of Victoria; Berthold Rittberger, Ludwig-Maximilians-Universität München

Recipient: Daniel Ziblatt, Harvard University

Title: "Conservative Parties and the Birth of Democracy." Cambridge University Press, 2017.

\section{Ernst B. Haas Dissertation Award}

The Ernst B. Haas Best Dissertation Award is given for the best dissertation on European politics and society filed during the previous year.

Award Committee: Jonathon Moses, Chair, Norwegian University of Science and Technology; J.P. Vollaard, University of Utrecht; Benedicta Marzinotto, University of Udine

Recipient: Volha Charnysh, Massachusetts Institute of Technology

Title: "Migration, Diversity and Economic Development: Post-WWII Displacement in Poland."

Honorable Mention: Marie De Somer, European Policy Center

Title: "Autonomy from Precedent: A Longitudinal Analysis of the EU Court of Justice's Case Law on Family Reunification Immigration."

\section{Best Paper Award}

The Best Paper Award is given for the best paper given on European Politics and Society section-sponsored panels at previous APSA Annual Meetings.

Award Committee: Catherine de Vries, Chair, University of Essex; Gabriel Goodliffe, Instituto Tecnológico Autónomo de México; Dionyssis G. Dimitrakopoulos, Birkbeck College

Recipient: Matthias Matthijs, Johns Hopkins University and Mark Blyth, Brown University

Title: "When Is It Rational to Learn the Wrong Lessons? Technocratic Authority, Social Learning, and Euro Fragility." Perspectives on Politics 16(1): 110-126.

\section{Peter Mair Memorial Award}

The Peter Mair Memorial Award will fund the travel of two young scholars to attend the APSA Annual Meeting. Named in memory of Peter Mair, one of the foremost scholars of European politics, the award is meant explicitly to enable young scholars of European politics without adequate funding to present a paper in one of the panels organized by the European Politics and Society section.

Award Committee: Mona Lena Krook, Chair, Rutgers University; Carlo Invernizzi Accetti, City University of New York; Sara Wallace Goodman, University of California, Irvine

Recipient: Dragana Svraka, University of Florida

Title: "Effects of Collective Ethnic Rights in Europe: Accommodation vs. Confrontation."

\section{SECTION 22. STATE POLITICS AND POLICY}

\section{Career Achievement Award}

The Career Achievement Award is given every biennium to a political scientist who has made a significant lifetime contribution to the study of politics and public policies in the American states.

Award Committee: Melinda Gann Hall, Chair, Michigan State University; Gerald Wright, Indiana University; Cherie Maestas, University of North Carolina at Charlotte

Recipient: Peverill Squire, University of Missouri, Columbia

\section{Christopher Z. Mooney Dissertation Award}

This award is given for the best dissertation in American state politics and policy completed during the previous calendar year.

Award Committee: Julianna Pacheco, University of Iowa; Vladimir Kogan, The Ohio State University; Robert Erikson, Columbia University

Recipient: Julia Payson, Stanford University

Title: "When Governments Lobby." Unpublished PhD Dissertation. Stanford University. 2017.

\section{Best Article Award}

This award recognizes the best journal article on US state politics or policy published during the previous calendar year in any peer-reviewed journal.
Award Committee: Christopher Warshaw, George Washington University; Rebecca Kreitzer, University of North Carolina at Chapel Hill; Lynda Powell, Rochester University

Recipients: James E. Monogan III, University of Georgia; David M. Konisky, Indiana University; Neal D. Woods, University of South Carolina

Title: "Gone with the Wind: Federalism and the Strategic Location of Air Polluters." American Journal of Political Science. 16(2):257-270.

\section{Virginia Gray Best Book Award}

This award is given annually to the best political science book published on the subject of US state politics or policy in the preceding three calendar years. Thus, books would be eligible to be considered for the award for three years.

Award Committee: Janine Parry, University of Arkansas; Meghan Leonard, Illinois State University; Kevin Banda, Texas Tech University

Recipients: William F. Franko, West Virginia University and Christopher Witko, South Carolina University

Title: The New Economic Populism: How States Respond to Economic Inequality. Oxford University Press. 2017.

\section{SPPQ Best Paper Award}

The State Politics and Policy Quarterly Best Paper Award is given for the best paper on state politics and policy presented at any professional meeting in the previous calendar year.

Award Committee:Justin Phillips, Columbia University; Danielle Thomsen, Syracuse University; Ngoc Phan, Hawaii Pacific University

Recipient: Mary Kroeger, University of Rochester

Title: "Bill Changes in State Legislatures."

\section{SECTION 23. POLITICAI COMMUNICATION}

\section{Timothy E. Cook Best Graduate Student Paper Award}

The Cook Award recognizes the best paper on political communication presented by a graduate student at the previous year's APSA Annual Meeting.

Award Committee: Yanna Krupnikov, Stony Brook University; Danielle Vinson, Furman University; Brian Weeks, University of Michigan 
Recipient: Kevin Munger, New York University

Title: "Experimentally Reducing Partisan Incivility on Twitter."

Recipient: Marc Trussler, Vanderbilt University

Title: "The Effects of High Information Environments on Local Accountability in the US House of Representatives."

\section{Paul Lazarsfeld Best Paper Award}

The Paul Lazarsfeld Award recognizes the best paper on political communication presented at the previous year's APSA Annual Meeting.

Award Committee: Andrew Chadwick, Loughborough University; Shelley Boulianne, MacEwan University; Jennifer Pan, Stanford University; Jason Reifler, University of Exeter

Recipients: Thomas J. Leeper, London School of Economics and Rune Slothuus, Aarhus University

Title: "Can Citizens Be Framed? How Information More than Emphasis Changes Political Opinions."

\section{Thomas E. Patterson Best Dissertation Award}

This award recognizes one outstanding doctoral dissertation in political communication annually. To be considered for the award, the dissertation research must pertain to some aspect of political communication.

Award Committee: Regina Lawrence, University of Oregon; Amber Boydstun, University of California, Davis; Nick Anstead, London School of Economics

Recipient: Katie McCabe, Princeton University

Title: "The Consequences of Imperfect Partisanship for Political Decisions." Princeton University, 2017.

Recipient: Juan Larosa Fuentes, Temple University

Title: "Communication and the Body Politic: Hillary Clinton's 2016 Presidential Campaign in Philadelphia's Latino Community." Temple University, 2017.

\section{David Swanson Career Achievement Award}

The David Swanson Career Achievement Award recognizes distinguished and sustained contributions to the field as planners, editors, and leaders and in roles that require time and energy, innovation, and personal dedication. The award honors David Swanson, one of the founders of Political Communication who gave exemplary service to the ICA Political Communication Division and the APSA Political Communication Section. In his memory, the ICA division presents the award every other year. The joint award committee includes representatives of the ICA division and APSA section. The ICA division chair appoints members with the advice of the APSA chair, and the committee receives nominations and generates additional candidates, deliberates on the pool of potential awardees, and makes a selection. The winner receives the award plaque at the annual business meeting of the ICA Political Communication Division. The award is given in evennumbered years.

Award Committee: Tamir Shaefer, Hebrew University of Jerusalem; Stuart Soroka, University of Michigan; Talia Stroud, University of Texas; Shanto Iyengar, Stanford University; Barbara Pfetsch, Freie Universitat Berlin

Recipient: Claes de Vreese, University of Amsterdam

\section{Doris Graber Outstanding Book Award}

The Doris Graber Outstanding Book Award is given to the most outstanding book in the field of political communication that was published in the past decade.

Award Committee: Sharon Jarvis, University of Texas at Austin; Mary Banwart, University of Kansas; Martin Johnson, Louisiana State University

Recipient: Amber Boystun, University of California Davis

Title: Making the News: Politics, the Media\& Agenda Setting. University of Chicago Press, 2013.

\section{Walter Lippmann Best Published Article Award}

The Walter Lippmann Best Published Article Award recognizes the best article published in the field of political communication in the previous calendar year.

Award Committee: Emily Thorson, Boston College; Ashley Muddiman, University of Kansas; John Ryan, Stony Brook University

Recipient: Jessica T. Feezell, University of New Mexico

Title: "Agenda-Setting Through Social Media: The Importance of Incidental News Exposure and Social Filtering in the Digital Era." Political Research Quarterly. 2017.
SECTION 24. POLITICS AND HISTORY

\section{J. David Greenstone Book Award}

The J. David Greenstone Book Award recognizes the best book in history and politics in the past two calendar years.

Award Committee: Saladin Ambar, Rutgers University; Rachel Beatty Reidl, Northwestern University; Daniel Wirls, University of California, Santa Cruz

Recipient: Paul Frymer, Princeton University Title: Building an American Empire: The Era of Territorial and Political Expansion. Princeton University Press, 2017.

\section{Mary Parker Follett Award for Best Article}

The Mary Parker Follett Award recognizes the best article on politics and history published in the previous year.

Award Committee: Mala Htun, University of New Mexico; Anna O. Law, Brooklyn College; Daniel Beland, University of Saskatchewan

Recipient: Jennifer M. Dixon, Villanova University

Title: "Rhetorical Adaptation and Resistance to International Norms." Perspectives on Politics. 15(1)

\section{Walter Dean Burnham Dissertation}

\section{Award}

The Walter Dean Burnham Award is given for the best dissertation in the field of politics and history.

Award Committee: Kathleen Sullivan, Ohio University; David Wilkins, University of Minnesota; Erik Kuhonta, McGill University

Recipient: Jeffrey Javed, Harvard University Title: "Land and Retribution: Morality, Mobilization, and Violence in China's Land Reform Campaign (1950-1952).”

\section{SECTION 25. POLITICAL ECONOMY}

\section{Michael Wallerstein Award}

The Michael Wallerstein Award is given for the best published article in political economy in the previous calendar year. Award Committee: Leslie Johns, University of California, Los Angeles; James Hollyer, University of Minnesota; Tim Hellwig, Indiana University

Recipient: In Song Kim, Massachusetts Institute of Technology

Title: "Political Cleavages within Industry: Firm-level Lobbying for Trade Liberalization." American Political Science Review. 111(1): 1-20. 


\section{William H. Riker Book Award}

The Best Book Award, named for William H. Riker, is given for the best book on political economy published during the past three calendar years.

Award Committee: Gary Cox, Chair, Stanford University; James Long, University of Washington; Matthew Winters, University of Illinois at Urbana

Recipient: Mark Dincecco and Massimiliano Onorato, University of Michigan

Title: From Warfare to Wealth. Cambridge University Press.

\section{Mancur Olson Best Dissertation Award}

The Best Dissertation Award, named for Mancur Olson, is given for the best dissertation in political economy completed in the previous two years.

Award Committee: Emily Sellars, Texas A\&M University; Lenka Bustikova, Arizona State University; Xian Huang, Rutgers University

Recipient: Pavithra Suryanarayan, Columbia University

Title: "Hollowing Out the State: Essays on Status Inequality, Fiscal Capacity, and Right-Wing Voting in India." Columbia University.

Honorable Mention: Junyan Jiang, The Chinese University of Hong Kong

Title: "Fragmented Unity: Patronage Politics and Authoritarian Resilience in China."

\section{Fiona McGillivray Prize Best Paper Award}

The Fiona McGillivray Prize is given for the best paper in political economy presented at the previous year's APSA Annual Meeting.

Award Committee: Alex Hertel Fernandez, Columbia University; Pia Raffler, Harvard University; Jose Fernandez Albertos, Centro de Ciencias Humanas y Sociales

Recipient: Agustina Paglayan, University of California, San Diego

Title: "Civil War, State Consolidation, and the Spread of Mass Education."

\section{SECTION 27. NEW POLITICAL SCIENCE}

\section{Christian Bay Best Paper Award}

The Christian Bay Award recognizes the best paper presented on a New Political Science panel at the previous year's APSA Annual Meeting.
Award Committee: Timothy Weaver, Chair, SUNY Albany; Wendy Wright, Bridgewater State University; Cary Fraser, Appalachian State University

Recipient: Priscilla Yamin and Alison Gash, University of Oregon

Title: "Illegalizing Families': State Status and Deportability."

\section{Michael Harrington Book Award}

The Michael Harrington Book Award recognizes an outstanding book that demonstrates how scholarship can be used in the struggle for a better world.

Award Committee: Peter Dauvergne, Chair, University of British Columbia; Chad Lavin, SUNY Buffalo; David A. Schultz, Hamline University; Richard Meagher, Randolph-Macon College

Recipient: Gordon Lafer, University of Oregon

Title: The One-Percent Solution: How Corporations Are Remaking American One State at a Time. ILR Press, 2017.

\section{Richard Cloward and Francis Fox Piven Award}

The Richard Cloward and Frances Fox Piven Award recognizes an activist group, in the region of the APSA Annual Meeting that puts the ideals of the New Political Science Section-"to make the study of politics relevant to the struggle for a better world"into practice.

Award Committee: Heike Schotten, Chair, University of Massachusetts, Boston; Kevin Brutneel, Babson College; Jeff Broxmeyer, The University of Toledo; Frances Fox Piven (Honorary), CUNY Graduate Center

Recipient: Young Abolitionists

\section{Charles A. McCoy Career Achievement Award}

The Charles A. McCoy Career Achievement Award recognizes a progressive political scientist who has had a long, successful career as a writer, teacher, and activist. Award Committee: Mark Kesselman, Chair, Columbia University; Timothy W. Luke, Virginia Tech; Joseph Peschek, Hamline University

Recipient: Cynthia Enloe, Clark University

\section{Stephen Eric Bronner Dissertation Award}

This award is for an outstanding political science dissertation finished within the previous year of the APSA Annual Meeting which exemplifies the commitment to use scholarship in the struggle for a better world.

Award Committee: Kevin Funk, Chair, Spring Hill College; Leonard Williams, Manchester University; Lucretia Garcia Iommi, Fairfield University; Stephen E. Bronner (Honorary), Rutgers University Recipient: Rafael Khachaturian, Indiana University

Title: "Discipline, Knowledge, and Critique: Marxist Theory and the Revival of the State in American Political Science, 1968-1989."

\section{SECTION 28. POLITICAL} PSYCHOLOGY

\section{Robert E. Lane Best Book Award}

The Robert E. Lane Award recognizes the best book in political psychology published in the past year.

Award Committee: Patrick Egan, Chair, New York University; Darren Davis, University of Notre Dame; Amy Lerman, University of California, Berkeley

Recipients: Kevin Arceneaux and Ryan J. Vander Wielen, Temple University

Title: Taming Intuition: How Reflection Minimizes Partisan Reasoning and Promotes Democratic Accountability. Cambridge University Press, 2017.

\section{Best Paper Award}

The Best Paper Award is given to the most outstanding paper in political psychology delivered at the previous year's APSA Annual Meeting.

Award Committee: Corrine McConnaughy, Chair, The George Washington University; Peter Dinesen, University of Copenhagen; Christopher Parker, University of Washington

Recipients: Thomas Leeper, London School of Economics and Rune Slothuus, Aarhus University

Title: "Can Citizens Be Framed? How Information More than Emphasis Changes Political Opinions."

\section{Best Dissertation Award}

The Best Dissertation Award is given for the best dissertation in political psychology filed during the previous year.

Award Committee: Michael Tesler, Chair, University of California, Irvine; Martin Bisgaard, Aarhus University; Ariel White, Massachusetts Institute of Technology Recipient:Adam Thai, Princeton University Title: "The Origin of Affluent Class Interests and Their Consequences for Inequality." 
SECTION 29. POLITICAL SCIENCE EDUCATION

\section{Craig L. Brians Award for Excellence in Undergraduate Research and Mentorship}

Established in 2014, this award will be awarded annually at the Teaching and Learning Conference, with recognition also given at the APSA annual Political Science Education section reception.

Award Committee: Michael Rogers, Arkansas Tech University; Maureen Feeley, University of California, San Diego; Tressa Tabares, American River College

Recipient: E. Fletcher McClellan, Elizabethtown College

\section{The Best APSA Conference Paper Award}

The Best APSA Conference Paper Award is given for the best presentation on undergraduate education at the past year's APSA Annual Meeting.

Award Committee: Terry Gilmour, Midland College; Erin Richards, Cascadia College; Cherie Strachan, Central Michigan University

Recipient: Donald M. Gooch, Stephen F. Austin State University

Title: "Structuring Civic Education: Assessing Civic Literacy Retention and Curricular Sequencing."

\section{The Distinguished Service Award}

This award may be given at the section meeting held at the APSA annual meeting. The awardee must have a strong record of exceptional and extensive contributions to the goals of the section, including the promotion of teaching and learning in the discipline and the scholarship of teaching.

Award Committee: Patrick McKinlay, Morningside College; Terry Gilmour, Midland College; Joseph Roberts, Roger Williams University

Recipient: John Ishiyama, University of North Texas

\section{SECTION 32. ELECTIONS, PUBLIC OPINION, AND VOTING BEHAVIOR}

\section{Warren E. Miller Prize}

The Warren E. Miller Prize is awarded every two or three years for an outstanding career of intellectual accomplishment and service to the profession in the Elections, Public Opinion, and Voting Behavior field.
Award Committee: Tali Mendelberg, Princeton University; Martin Rosema, University of Twente; Vincent Hutchings, University of Michigan; Barbera Norrander, University of Arizona Recipient: Kay Schlozman, Boston College

\section{Philip E. Converse Best Book Award}

The Philip E. Converse Book Award is given for an outstanding book in the field published at least five years before.

Award Committee: Marc Hetherington, University of North Carolina at Chapel Hill; Jeffery Mondak, University of Illinois Urbana - Champaign; Sarah Gershon, Georgia State University

Recipient: Jennifer L. Hochschild, Harvard University

Title: What's Fair? American Beliefs about Distributive Justice. Harvard University Press, 1986.

\section{Emerging Scholar Award}

The Emerging Scholar Award is awarded to the top scholar in the field who is within 10 years of her or his PhD.

Award Committee: Deborah Schildkraut, Tufts University; Shana Kushner Gadarian, Syracuse University; Brendan Nyhan, Dartmouth College; Kevin Arceneaux, Temple University

Recipient: Samara Klar, University of Arizona; Michael Tesler, University of California, Irvine

\section{Best Paper Award}

The Best Paper Award is given for the best paper delivered at the previous year's APSA Annual Meeting.

Award Committee: Christopher Johnston, Duke University; Alexandra Filindra, University of Illinois at Chicago; Shane Singh, University of Georgia; Scott Matthews, Memorial University

Recipients: Cecilia Mo, University of California, Berkeley and Katherine Conn, Columbia University

Title: "When do the Advantaged See the Disadvantages of Others? A QuasiExperimental Study of National Service."

\section{Best Article in Political Behavior Award}

This award is for the best article published in Political Behavior in the previous calendar year.

Award Committee: Cecilia Mo, University of California, Berkeley; Ruth Dassonneville, Université de Montréal; Ashley Jardina, Duke University
Recipient: Kevin Munger, New York University

Title: "Tweement Effects on the Tweeted: Experimentally Reducing Racial Harassment." Political Behavior 39(3): 629-649.

\section{John Sullivan Award}

The John Sullivan Award for the best paper by a graduate student on a panel sponsored by the APSA Organized Section on Elections, Public Opinion, and Voting Behavior at the previous APSA Annual Meeting. Award Committee: Hans Hassell, Cornell College; Amanda Bittner, Memorial University; Nicholas Valentino, University of Michigan

Recipient: Elizabeth Connors, Stony Brook University

Title: "Political Values as Partisan Social Norms: The Social Context on Value Endorsement."

\section{Graduate Student Travel Awards}

Multiple grants awarded to graduate students who are authors or coauthors of papers on a panel or poster session sponsored by the section at the 2017 Annual Meeting. Award Committee: Candis Watts Smith, University of North Carolina at Chapel Hill; Jonathan Winburn, University of Mississippi; Julian Wamble, Massachusetts Institute of Technology

Recipient: Elizabeth Connors, Stony Brook University

\section{SECTION 34. INTERNATIONAL} HISTORY AND POLITICS

\section{Robert L. Jervis and Paul W. Schroeder Best Book Award}

This award may be granted to a singleauthored or multi-authored book, or to an edited volume. The award will be given to works published in the calendar year prior to the year of the APSA Annual Meeting at which the award is presented. The copyright date of a book will establish the relevant year. Award Committee: Lisa Blayes, Chair, Stanford University; Rosella Capella Cappella Zielinski, Boston University;Jason Sharman, Cambridge University

Recipient: Catherine Lu, McGill University Title: Justice and Reconciliation in World Politics. Cambridge University Press, 2017.

\section{Outstanding Article Award in International History and Politics}

The Outstanding Article Award in International History and Politics recognizes exceptional peer-reviewed journal articles 
representing the mission of the International History and Politics Section of the APSA, including innovative work that brings new light to events and processes in international politics, encourages interdisciplinary conversations between political scientists and historians, and advances historiographical methods. The Outstanding Article Award is given to a published article that appeared in print in the calendar year preceding the APSA Annual Meeting at which the award is presented. It may be granted to an article that is single- or coauthored. The year of final journal publication, as detailed by print citation, establishes eligibility.

Award Committee: Seva Gutinsky, Chair, University of Toronto; Nicolas Miller, Dartmouth College; Sheena Greitens, University of Missouri

Recipients: Brendan Green, University of Cincinnati and Austin Long, RAND Corporation

Title: “The MAD Who Wasn't There: Soviet Reactions to the Late Cold War Nuclear Balance." Security Studies 26(4): 6o6-641.

\section{SECTION 35. COMPARATIVE DEMOCRATIZATION}

\section{Juan Linz Best Dissertation Award}

This award is given for the best dissertation in the comparative study of democracy completed and accepted in the two calendar years immediately prior to the APSA Annual Meeting.

Award Committee: Karen E. Ferree, Chair, University of California, San Diego; Avital Livny, University of Illinois, UrbanaChampaign; Matthew Rhodes Purdy, Washington University in St. Louis

Recipient: Soledad Prillaman, University of Oxford

Title: "Why Women Mobilize: Dissecting and Dismantling India's Gender Gap in Political Participation." Harvard University, 2017.

Honorable Mention: Elizabeth Nugent, Harvard University

Title: "The Political Psychology of Repression and Polarization in Authoritarian Regimes." Princeton University, 2017.

\section{Best Book Award}

This award is given for the best book in the field of comparative democratization published in 2016 (authored, coauthored, or edited).
Award Committee: Stephen Haggard, Chair, University of California, San Diego; Sheena Chestnut Greitens, University of Missouri; Erik S. Herron, West Virginia University Recipient: Daniel Ziblatt, Harvard University Title: "Conservative Parties and the Birth of Democracy." Cambridge University Press, 2017.

\section{Best Article Award}

Single-authored or coauthored articles focusing directly on the subject of democratization and published in 2016 are eligible for this award.

Award Committee: Kurt Weyland, Chair, University of Texas at Austin; Milan Svolik, Yale University; Sarah Shair-Rosenfield, Arizona State University

Recipient: Michael Albertus, University of Chicago

Title: "Landowners \& Democracy: The Social Origins of Democracy Reconsidered." World Politics 69(2): 233-276.

Honorable Mention: Bryn Rosenfeld, University of Southern California

Title: "Reevaluating the Middle-Class Protest Paradigm: A Case-Control Study of Democratic Protest Coalitions in Russia." American Poltical Science Review 111(4): $637-652$.

\section{Best Field Work Award}

This prize rewards dissertation students who conduct especially innovative and difficult fieldwork. Scholars who are currently writing their dissertations or who complete their dissertations in 2017 are eligible.

Award Committee: Daniel Corstange, Chair, Columbia University; Nicholas Barnes, Brown University; Sarah Bush, Temple University

Recipient:Egor Lazarev, Columbia University Title: "Laws in Conflict: Legacies of War and Legal Pluralism in Chechnya." Columbia University.

Honorable Mention: Elizabeth Nugent, Harvard University

Title: "The Political Psychology of Repression and Polarization in Authoritarian Regimes." Princeton University.

Honorable Mention: Şule Yaylaci, Yale University

Title: "Trust in Civil Wars: The Implications of Conflict Character and Threat on Political and Social Trust." University of British Columbia.

\section{Best Paper Award}

Given to the best paper on Comparative Democratization presented at the pre- vious year's APSA Convention. Papers must be nominated by panel chairs or discussants.

Award Committee: Lenka Bustikova, Chair, Arizona State University; Cristina Corduneanu-Huci, Central European University; Jonathan Krieckhaus, University of Missouri

Recipient: Elizabeth Nugent, Harvard University

Title: "The Psychology of Repression and Polarization in Authoritarian Regimes."

Honorable Mention: Dan Treisman, University of California, Los Angeles

Title: "Democracy by Mistake."

\section{SECTION 36. HUMAN RIGHTS}

\section{Best Book Award}

The best book award recognizes the best book on human rights written by a political scientist and published in the previous two years.

Award Committee: Patrice C. McMahon, Chair, University of Nebraska; Bethany Barratt, Roosevelt University; Alison Dundes Renteln, University of Southern California Recipient: Manfred Nowak, University of Vienna

Title: Human Rights or Global Capitalism. University of Pennsylvania Press, 2017.

\section{Best Dissertation Award}

Award Committee: Alison Brysk, University of California, Santa Barbara

Recipient: Suparna Chaudhry, Yale University Title: "The Assault on Democracy Assistance: Explaining State Repression of NGOs."

\section{SECTION 37. QUALITATIVE AND MULTI-METHOD RESEARCH}

\section{Giovanni Sartori Book Award}

The Giovanni Sartori Book Award honors Giovanni Sartori's work on qualitative methods and concept formation, and especially his contribution to helping scholars think about problems of context as they refine concepts and apply them to new spatial and temporal settings. The award is intended to encompass two types of contributions: new research on methodology per se (i.e., studies that introduce specific methodological innovations or that synthesize and integrate methodological ideas in a way that is in itself a methodological contribution) and substantive work that is an exemplar for the application of qualitative methods. 
Award Committee: Anna Grzymala-Busse, Chair, Stanford University; Nicholas Weller, University of California, Riverside; Zachariah Mampilly, Vassar College Recipient: Alisha Holland, Princeton University

Title: Forbearance as Redistribution: The Politics of Informal Welfare. Cambridge University Press.

\section{Alexander L. George Article-Chapter Award}

The Alexander L. George Article Award honors Alexander George's contributions to the comparative case-study method, including his work linking that method to a systematic concern with research design, and his contribution of developing the idea and the practice of process tracing. This award may be granted to a journal article or to a chapter in an edited volume that stands on its own as an article. The award will be given to an article or book chapter published in the calendar year prior to the year of the APSA Annual Meeting at which the award is presented, with the date of publication being established by the journal issue for articles and the copyright date of the book for chapters.

Award Committee: Nahomi Ichino, Chair, University of Michigan; Seva Gunitsky, University of Toronto; Carsten Schneider, Central European University

Recipient: Calla Hummel, University of Texas at Austin

Title: "Disobedient Markets: Street Vendors, Enforcement, and State Intervention in Collective Action." Comparative Political Studies 50(11): 1524-1555.

\section{Sage Paper Award}

The Sage Paper Award honors Sara and George McCune, who founded and sustained Sage Publications as a leading publisher of social science methodologyincluding very centrally qualitative methods. This award will be given to a paper presented at the previous Annual Meeting of the APSA.

Award Committee: Alison Post, Chair, University of California, Berkeley; Ryan Griffiths, University of Sydney; Noah Nathan, University of Michigan

Recipients: Ana Catalano Weeks, Harvard University

Title: "Why Are Gender Quota Laws Adopted by Men? The Role of Inter-and Intra-Party Competition."

\section{David Collier Mid-Career} Achievement Award

The award honors David Collier's contributions-through his research, graduate teaching, and institution-building-as a founder of the qualitative and multimethod research movement in contemporary political science. The award will be presented annually to a mid-career political scientist to recognize distinction in methodological publications, innovative application of qualitative and multi-method approaches in substantive research, and/or institutional contributions to this area of methodology.

Award Committee: Melani Cammett, Chair, Harvard University; Andrew Bennett, Georgetown University; Alan Jacobs, University of British Columbia; Lauren Morris MacLean, Indiana University

Recipient: Jason Seawright, Northwestern University

\section{SECTION 38. SEXUALITY AND POLITICS}

\section{Cynthia Weber Best Conference Paper Award}

The Cynthia Weber Best Conference Paper Award recognizes the best paper exploring sexuality and politics presented at the previous year's APSA Annual Meeting.

Award Committee:Charles Gossett, California State University, Sacramento; Erin MayoAdam, Hunter College; R.G. Cravens, Bowling Green State University

Recipient: R.G. Cravens, Bowling Green State University

Title: "Out for Social Justice: Predicting Queer \& Liberationist Public Attitudes." APSA 2017.

\section{Kenneth Sherrill Best Dissertation Award}

The Best Dissertation Award recognizes the best dissertation on sexuality and politics completed and successfully defended in the previous two calendar years.

Award Committee: Courtenay Daum, Colorado State University; Eric van der Vort, Syracuse University; Jennifer Raymond, Union Institute \& University

Recipient: Erin Mayo-Adam, Hunter College

Title: "Queer Alliances: Paradoxes and Power in the Formation of Rights-Based Movement Coalitions." University of Washington, 2018.
SECTION 39. HEALTH POLITICS AND POLICY

\section{Leonard S. Robins Best Paper Award}

The Leonard S. Robins Best Paper on Health Politics and Policy Award honors the late Len Robins, who through his presence and gentle questioning at virtually every health politics panel, graciously nurtured the scholarship of both junior and senior scholars. Award Committee: Patricia Strach, SUNY at Albany; Frank Thompson, Rutgers University; Scott Greer, University of Michigan Recipient: Isabel M. Perera, University of Pennsylvania

Title: "Deinstitutionalization Revisited: The Role of Public Psychiatrists in France and The United States."

\section{Health Politics and Policy: Public Engagement Award}

This award recognizes an individual who has been working to improve health and the health care system by actively engaging in politics and policy making.

Award Committee: Colleen Grogan, University of Chicago; Julia Lynch, University of Pennsylvania; Sue Tolleson-Rinehart, University of North Carolina; Sarah Gollust, University of Minnesota; David Jones, Boston University; Scott Greer, University of Michigan; Shanna Rose, Claremont McKenna College

Recipient: John McDonough, Harvard University

\section{SECTION 40. CANADIAN POLITICS}

\section{Mildred A. Schwartz Lifetime Achievement Award}

The Mildred A. Schwartz Lifetime Achievement Award recognizes scholarship and leadership in bringing the study of Canadian Politics to the international political science community.

Award Committee: Daniel Cohn, Chair, York University; Mildred Schwartz, University of Illinois - Chicago; Charles Doran, Johns Hopkins University; Mireille Lalancette, Université du Québec à Trois-Rivières; Patrick Fournier, Université de Montréal Recipient: André Blais, Université de Montréal

\section{Seymour Martin Lipset Best Book Award}

The Seymour Martin Lipset Best Book Award is given to honor a significant contemporary contribution to the scholarship 
on Canadian politics, Canada in a comparative perspective, or a comparative analysis of Canada with other countries, particularly the United States.

Award Committee: Ross E. Burkhart, Chair, Boise State University; Joanna Everitt, University of New Brunswick, Saint John; Christopher Alcantara, Western University; Kenneth Cosgrove, Suffolk University; Greg Lyle, Innovative Research Group

Recipient: Debra Thompson, University of Oregon

Title: The Schematic State: Race, Transnationalism, and the Politics of the Census. Cambridge University Press, 2016.

\section{SECTION 41. POLITICAL NETWORKS}

\section{Political Ties Award}

This award is given on a biennial basis to the best article published on political networks.

Award Committee: Alex Hughes, Chair, University of California, Berkeley; Katya Ognyaanova, Rutgers University; Brandon Kinne, University of California, Davis

Recipients: Matthew T. Pietryka, Florida State University and Donald DeBats, Flinders University

Title: "It's Not Just What You Have, but Who You Know: Networks, Social Proximity to Elites, and Voting in State and Local Elections." American Political Science Review.

\section{Best Conference Paper Award}

This award is given annually to the best paper on political networks presented by a faculty person delivered at a political science conference in the previous year. Award Committee: Rachel Blum, Chair, Miami University; Sean Richey, Georgia State University; Alison Craig, University of Texas at Austin

Recipients: Paul Djupe, Denison University; Anand E. Sokhey, University of Colorado at Boulder; Amanda Friesen, Indiana University, Purdue University Indianapolis

Title: "Social Dominance Orientations, Gender, and the Engagement Gap in American Politics."

\section{John Sprague Award}

This award is given annually to the best paper on political networks presented by a graduate student delivered at a political science conference in the previous year. There is a fund that supports this award and the award includes a cash award that comes from the fund.

Award Committee: Lauren Ratliff Santoro, Chair, University of Texas at Dallas; Sarah Bauerle Danzman, Indiana University; Isabella Alcaniz, University of Maryland

Recipient:Joshua McCrain, Emory University Title: "Revolving Door Lobbyists and the Value of Congressional Staff Connections." Journal of Politics.

\section{Career Achievement Award in Political Networks}

The Political Networks Section of the American Political Science Association calls for nominations for the inaugural presentation of The Career Achievement Award in Political Networks. This award is given to a scholar who has made major contributions that have had a longterm impact on the study of political networks.

Award Committee: Meredith Rolfe, University of Massachusetts, Amherst; Mark Lubell, University of California, Davis; Alex Montgomery, Reed College

Recipient: Robert Huckfeldt, University of California, Davis; Mike Ward, Duke University

\section{Best Substantive Poster Award}

This award is given annually at the Political Networks Conference and is awarded to the best posters on political networks.

Award Committee: Lauren Ratliff Santoro, University of Texas at Dallas; Nils Ringe, University of Wisconsin-Madison; Lorien Jasny, University of Exeter; Brandon Kinne, University of California, Davis

Recipient: Andrew Fox, University of Oklahoma

Title: "Strings of Traitors: Networks and the Contagion of Violence in Khmer Rouge Era Cambodia."

\section{Best Methodological Poster Award}

This award is given annually at the Political Networks Conference and is awarded to the best posters on political networks. Award Committee: Lauren Ratliff Santoro, University of Texas at Dallas; Nils Ringe, University of Wisconsin-Madison; Lorien Jasny, University of Exeter; Brandon Kinne, University of California, Davis

Recipient: Benjamin Campbell, Ohio State University

Title: "Detecting Heterogeneity and Inferring Latent Roles in Longitudinal Networks using the Ego-TERGM."
SECTION 42. EXPERIMENTAL RESEARCH

\section{Best Paper Award}

The Best Paper Award recognizes a paper that was scheduled to be presented at the APSA Annual Meeting and features experimental research.

Award Committee: Miriam Golden, Chair, University of California, Los Angeles; Jennifer Jerit, Stony Brook University; Kim Twist, San Diego State University Recipients: Guy Grossman, University of Pennsylvania and Kristin Michelitch, Vanderbilt University

Title: "Information Dissemination, Competitive Pressure and Politician Performance between Elections: A Field Experiment in Uganda."

\section{Best Book Award}

The Best Book Award recognizes the best book published in 2016 that either uses or is about experimental research methods in the study of politics.

Award Committee: Daniel Rubenson, Chair, Ryerson University; Jaime Settle, College of William \& Mary; Leonie Huddy, Stony Brook University

Recipients: Vin Arceneaux and Ryan Vander Wielen, Temple University

Title: Taming Intuition: How Reflection Minimizes Partisan Reasoning and Promotes Democratic Accountability. Cambridge University Press, 2017.

Recipient: Ryan Enos, Harvard University Title: The Space Between Us: Social Geography and Politics. Cambridge University Press, 2017.

\section{Best Dissertation Award}

The Best Dissertation Award recognizes the best dissertation completed in calendar year 2016 that utilizes experimental methods on substantive questions about politics or makes a fundamental contribution to experimental methods.

Award Committee: Cesi Cruz, University of British Columbia; Horacio Larreguy, Harvard University; Johannes Urpelainen, Johns Hopkins University

Recipient: Saad Gulzar, Stanford University Title: "Essays on the Political Economy of Development in South Asia."

Recipient: Pia Raffler, Harvard University Title: "Information, Accountability, and Political Elite Behavior."

\section{Public Service Award}

Many experiments only occur thanks to the assistance of nonresearchers who provide 
access to resources and data. This award recognizes a special form of public service, the facilitation of randomized experiments in political science by those outside the academy.

Award Committee: Jake Bowers, Chair, University of Illinois, Urbana-Champaign; Pia Raffler, Harvard University; Fernando Rosenblatt, Universidad Diego Portales Recipient: Matt Morrison, Working America

\section{SECTION 43. MIGRATION AND CITIZENSHIP}

\section{Best Paper Award}

This award recognizes the best paper on migration and/or citizenship presented at the previous APSA Annual Meeting (either as part of a panel or poster session).

Award Committee: Saskia Bonjour, University of Amsterdam; Charlotte Cavaille, Georgetown University; Jacqueline Chattopadhyay, University of North Carolina at Charlotte

Recipients: Claire L. Adida, University of California, San Diego; Adeline Lo, Princeton University; Melina Platas, New York University Abu Dhabi

Title: "Engendering Empathy, Begetting Backlash: American Attitudes towards Syrian Refugees."

\section{Best Dissertation Award}

Award for best dissertation on migration and/or citizenship accepted in the previous calendar year.

Award Committee: Jeremy Ferwerda, Dartmouth College; Katrina Burgess, Tufts University; Fanny Lauby, William Paterson University

Recipient:Volha Charnysh, Harvard University Title: "Migration, Diversity, and Economic Development: Post WWII Displacement in Poland."

Recipient: Kelsey Norman, University of California, Irvine

Title: Reluctant Reception: Understanding Migration and Refugee Policy in Egypt, Morocco and Turkey

\section{Best Article Award}

This award recognizes the best article on migration and/or citizenship accepted in the previous calendar year.

Award Committee: Maarten Vink, Maastricht University; Elizabeth Cohen, Syracuse University; Jamie Monogan, University of Georgia

Recipient: Alex Street, Carroll College; Michael Jones-Correa, University of Pennsylvania; Chris Zepeda-Millán, University of California, Berkeley

Title: "Political Effects of Having Undocumented Parents." Political Research Quarterly 70(4): 818-832.

\section{Best Book Award}

The Best Book Award recognizes the best book on migration and/or citizenship published in the previous year.

Award Committee: Terri Givens, Menlo College; Mary McThomas, University of California, Irvine; Filiz Garip, Cornell University Recipient: Margaret E. Peters, University of California, Los Angeles

Title: Trading Barriers: Immigration and the Remaking of Globalization. Princeton University Press, 2017.

\section{Best Chapter Award}

This award recognizes the best chapter on migration and/or citizenship published (i.e., printed) in the previous calendar year. AwardCommittee:MatthewWright,American University; Antje Ellermann, University of British Columbia; Anna Sampaio, Santa Clara University

Recipient:Jacqueline Stevens, Northwestern University

Title: "The Alien Who is a Citizen," In Citizenship in Question: Evidentiary Birthright Statelessness, B.N. Lawrence and J. Stevens. Duke University Press.

\section{SECTION 45. CLASS AND INEQUALITY}

\section{Best Paper Award}

This award recognizes the best paper presented on the topic of economic or social class inequality at the APSA Annual Meeting.
Award Committee: Ray La Raja, University of Massachusetts Amherst; Elizabeth Rigby, George Washington University

Recipients: Elizabeth Suhay, American University; Marko Klašnja, Georgetown University; Gonzalo Rivero, Westat

Title: "Ideology of Affluence: Explanations for Inequality and Political Attitudes among Rich Americans."

\section{SECTION 47. AMERICAN POLITICAL} THOUGHT

\section{Best Book in American Political Thought}

The Best Book in American Political Thought Award will be chosen every year by the section council.

Award Committee: Phillip Munoz, University of Notre Dame; Justin Dyer, University of Missouri; Natalie Taylor, Skidmore College

Recipient: Forrest Nabors, University of Alaska at Anchorage

Title: From Oligarchy to Republicanism: The Great Task of Reconstruction. University of Missouri Press, 2017.

\section{Best Article in the Journal of American Political Thought}

The best article in American Political Thought will be chosen every year by the section council from among the articles published in the journal American Political Thought.

Award Committee: James Ceaser, University of Virginia; Clement Fatovic, Florida International University; Daniel Klinghard, College of the Holy Cross

Recipient: Matthew Brogdon, University of Texas at San Antonio

Title: "Constitutional Text and Institutional Development: Consenting the Madisonian Compromise in the First Congress." Journal of American Political Thought. 